УДК 576.31: 611.018.26:612.419

(C) 2017

Ковпак В. В., кандидат ветеринарних наук, докторант

(науковий консультант - доктор ветеринарних наук А. Й. Мазуркевич)

Ковпак О. C., аспірант

(науковий керівник - доктор ветеринарних наук А. Й. Мазуркевич)

Національний університет біоресурсів і природокористування України

\title{
ПОРІВНЯЛЬНА ХАРАКТЕРИСТИКА ФЕНОТИПОВИХ ЗМІН КУЛЬТУР КЛІТИН ЖИРОВОЇ ТКАНИНИ ТА КІСТКОВОГО МОЗКУ В ПРОЦЕСІ КУЛЬТИВУВАННЯ
}

\section{Рецензент - доктор ветеринарних наук С. П. Долецький}

У статті описані дані щзодо зміни фенотипу культур клітин жирової тканини (ККЖТ) та кісткового мозку (КККМ) у прочесі культивування. Дослідження первинних культур клітин кісткового мозку та жирової тканини щура показали, що вони морфологічно гетерогенні, у їх склад входили: невелика кількість клітин полігональної форми, а основну масу складали фібробластоподібні. За подальшого культивування відмічали процес переходу від гетерогенних культур на нульовому пасажі до найбільш гомогенних у кінці дослідження. Нами були відмічені відмінності у імунофенотипі культур клітин кісткового мозку та жирової тканини, які не зникали з пасажами.

Ключові слова: культура клітин, кістковий мозок, жирова тканина, імунофенотипування, морфологія, CD-маркери.

Постановка проблеми. Регенеративна терапія 3 кожним роком вимагає все більшої гарантії безпечності та ефективності клітинного матеріалу, тому обрання оптимальних джерел отримання клітин є одним з їі ключових етапів.

Аналіз основних досліджень і публікацій, у яких започатковано розв'язання проблеми. На сьогодні в якості джерела стовбурових клітин дорослих донорів досить добре досліджено кістковий мозок. Кістковий мозок - єдина тканина дорослого організму, яка в нормі складається з незрілих, недиференційованих і низько диференційованих клітин, так званих стовбурових клітин [25]. Доведено, що мезенхімальні та ендотеліальні клітини що містяться у кістковому мозку, здатні розвиватися в різноманітні негемопоетичні клітини - остеокласти, хондроцити, адипоцити, епітелій [5, 14].

Альтернативним джерелом отримання клітинного матеріалу є жирова тканина, 3 якої вони можуть бути отримані за допомогою менш інвазивних методів у значно більших кількостях, у порівнянні з кістковим мозком. У склад жирової тканини входять жирові клітини - адипоцити, а також клітини, що складають стромально- васкулярну фракцію (Stromal Vascular Fraction SVF): преадипоцити, ендотеліальні та гладком'язові клітини кровоносних судин, периваскулярні фібробласти і підтримуюча волокниста колагенова строма [1, 11]. Стовбурові клітини, що містяться у жировій тканині, мультипотентні. Вони здатні диференціюватися у різноманітні клітинні лініі, зокрема жирову, кісткову, хрящову, нервову тканини, ендотелій $[33,16]$ і клітини печінки [9, 27].

Трансплантація культур клітин має значні перспективи у лікуванні багатьох захворювань. Для того, щоб забезпечити базу для подальших досліджень в області регенеративної медицини, було проаналізовано клітини отримані з кількох джерел. Це дослідження представляє порівняння зміни фенотипових ознак клітин задля створення експериментальної системи оцінки та вибору оптимального джерела клітинного матеріалу.

Мета дослідження - порівняти морфологічні та фенотипові зміни культури клітин жирової тканини та кісткового мозку 3 першого до четвертого пасажу.

Завдання: отримати культури клітин кісткового мозку та жирової тканини, прослідкувати морфологічні та фенотипові зміни в отриманих культурах у процесі культивування та проаналізувати отримані результати.

Матеріали і методи дослідження. Експерименти на тваринах були проведені 3 дотриманням вимог Закону України «Про захист тварин від жорстокого поводження» (ст. 230 від 2006 року). У досліді використали 3-х самців не лінійних щурів віком 4 місяці та 9 не лінійних щуренят 12-денного віку. Евтаназію дослідних тварин здійснювали шляхом декапітації під ефірним наркозом.

Отримання культури клітин жирової тканини (ККЖТ) здійснювали з підшкірної жирової клітковини за стандартною методикою $[10,11,18]$ у власній модифікації. Культуру клітин кісткового 


\section{ВЕТЕРИНАРНА МЕДИЦИНА}

мозку (КККМ) отримували 3 кісткового мозку стегнових, великогомілкових та плечових кісток щурів за стандартною методикою $[3,18]$. Одержану клітинну масу культивували у стандартному середовищі: $80 \%$ - DMEM; $20 \%$ - FBS; 10 мкл/см ${ }^{3}$ - антибіотика-антимікотика «Sigma», США) (рис. 1); у $\mathrm{CO}_{2}$ інкубаторі за $37^{\circ} \mathrm{C}$ та $5 \%$ концентрації $\mathrm{CO}_{2}$ [3], до конфлюентності 90$100 \%$ (рис. 2).

Клітини знімали за стандартною методикою (розчином 0,25 \% трипсин/ЕДТА) [3]. Подальше пасажування здійснювалось у розведенні 1:3. Мікроскопічний аналіз і оцінку культури здійснювали за допомогою інвертованого мікроскопа Axiovert 40 (Карл Цейс).

Контроль зміни фенотипу проводили шляхом виявлення CD-маркерів (CD10, CD38, CD34, CD45, CD48, CD54, CD56, CD66e, CD96, CD227, CD3266, CD пан-кератин). Підготовку препаратів здійснювали за стандартною методикою) [3]. Аналіз результатів проводили за кількістю клітин з експресією (зелене свічення клітин) та оцінювали за допомогою класичного методу H-Score: $\mathrm{S}=1 \times \mathrm{A}+2 \times \mathrm{B}+3 \times \mathrm{C}$, де $\mathrm{S}-$ показник «H-Score», значення якого знаходяться у межах від 0 (білок не експресується) до 300 (сильна експресія у $100 \%$ клітин); А - клітини зі слабкою експресією; В - відсоток клітин 3 помірною експресією білка; С - відсоток клітин із сильною експресією. Ступінь експресії визначали як негативний, якщо число балів було в діапазоні від 0 до 50; низький - від 51 до 100; помірний - від

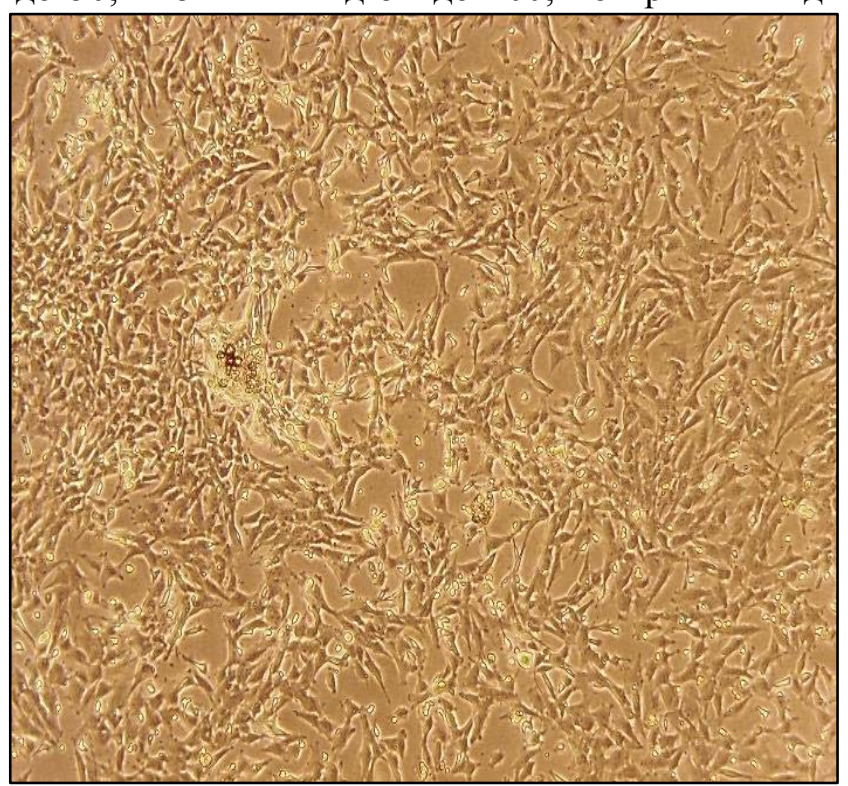

Рис. 1. Мікрофотографія культури клітин кісткового мозку in vitro, 7-ма доба культивування (0-й пасаж). Нативний препарат. ок. $\times 10$, об $\times 5$
101 до 200; високий - 201 та вище [6]. Дослідження здійснювали за допомогою флуоресцентного мікроскопа Leica DMR (Німеччина).

Результати досліджень. Порівняльна характеристика морфології культур клітин жсирової тканини та кісткового мозку. Первинна культура адгезивних клітин жирової тканини та кісткового мозку щурів характеризувалася морфологічною гетерогенністю. Протягом декількох днів, після висівання спостерігали значну кількість слабоадгезивних округлих клітин, які видалялись у процесі пасажування. Починаючи 3 3-го дня для КККМ (рис. 1) та 5-го - для ККЖТ відмічали рівномірний ріст фібробластоподібних клітин (рис. 2). Первинна ККЖТ досягала конфлюентності 90-100\% у середньому за 14 днів, КККМ - за 8 днів.

У процесі субкультивування час досягнення конфлюентності 70-80\% становив 4 доби для ККЖТ, та 3 доби для КККМ протягом 4 пасажів. На першому пасажі відмічали гетерогенність культур як кісткового мозку (рис. 3), так і жирової тканини (рис. 4), у їх склад входили: невелика кількість клітин полігональної форми та фібробластоподібні клітини. 3 кожним пасажем кількість клітин полігональної форми зменшувалась як у ККЖТ, так і КККМ. На четвертому пасажі відмічали найбільший гомогенний склад культур. Морфологія на 4-му пасажі характеризувалася переважно фібробластоподібною структурою (рис. 5, 6).

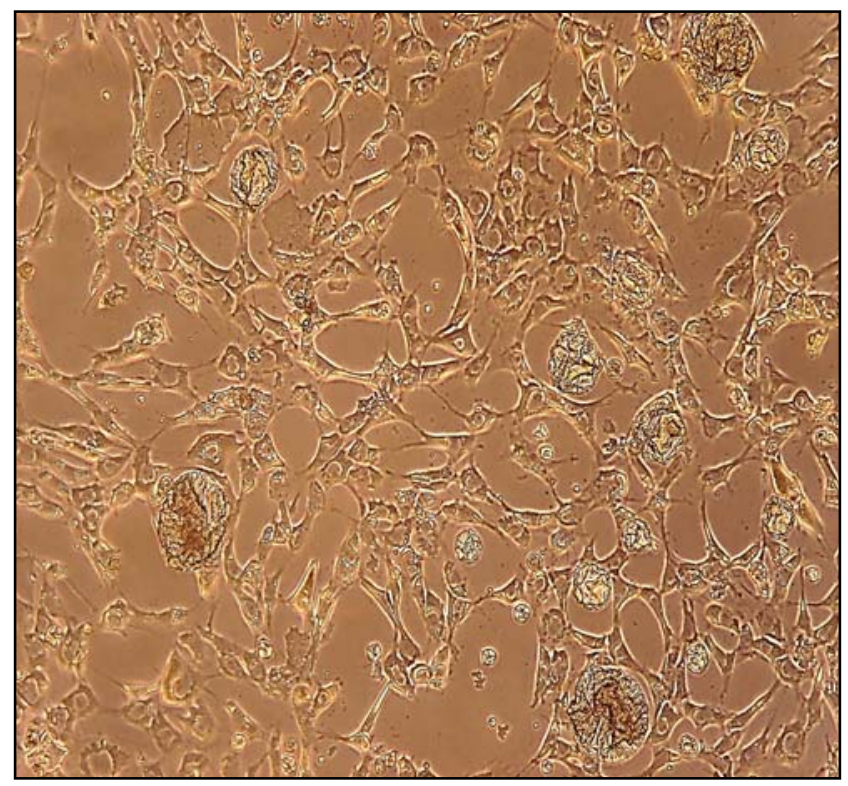

Рис. 2. Мікрофотографія колонії культури клітин жирової тканини іn vitro, 7-ма доба культивування. Нативний препарат ок. $\times 10$, об. $\times 10$ 


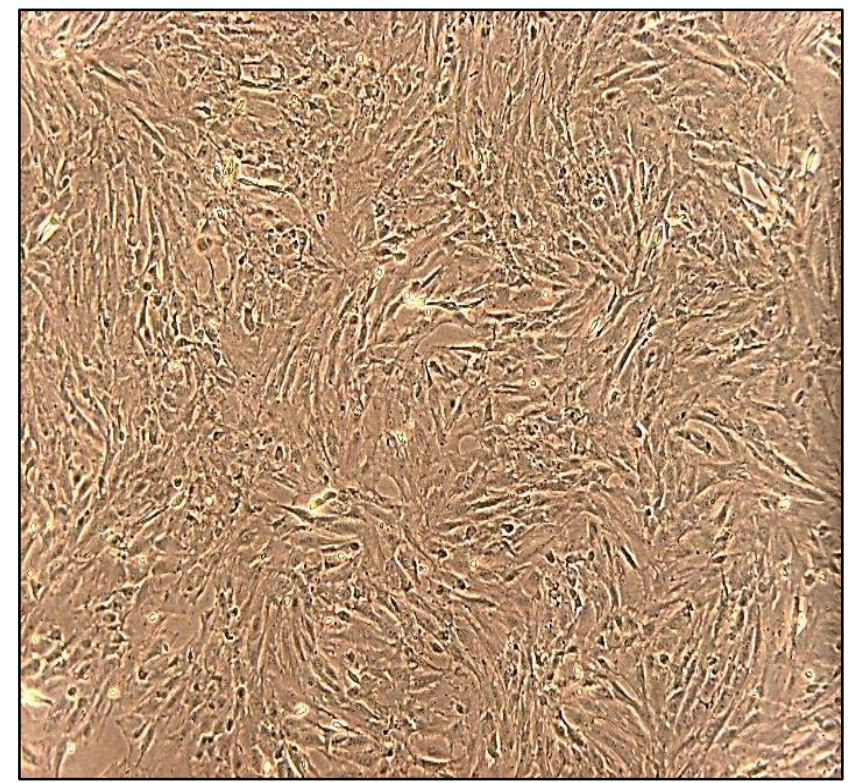

Рис. 3. Мікрофотографія моношару культури клітин кісткового мозку in vitro, 1-й пасаж. Нативний препарат. ок. $\times 10$, об $\times 5$

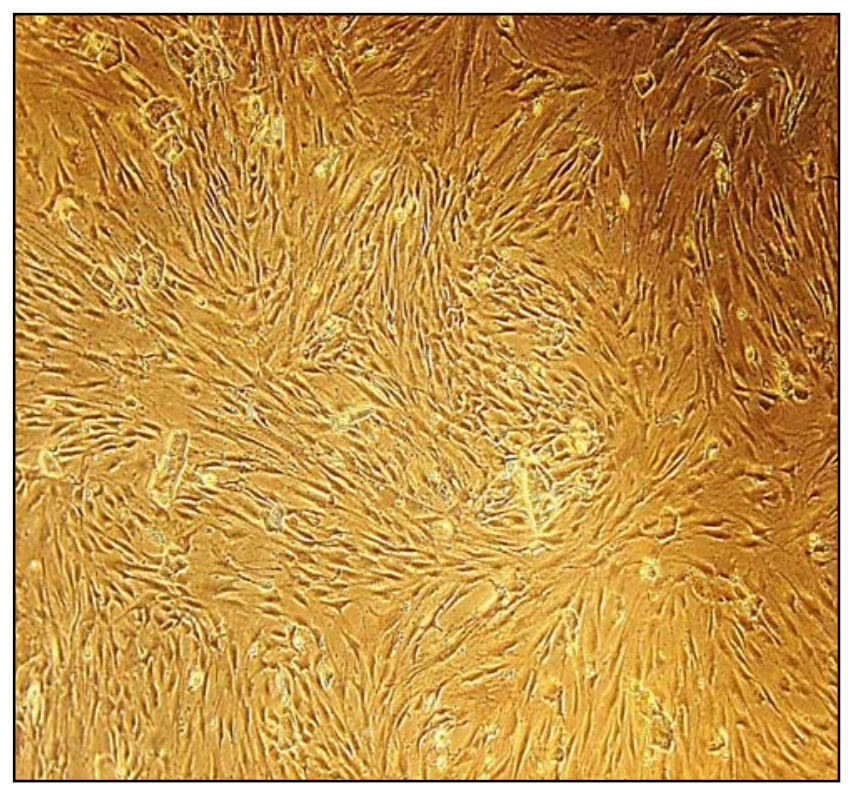

Рис. 5. Мікрофотографія моношару культури клітин жирової тканини іn vitro, 4-й пасаж. Нативний препарат. $о \kappa . \times 10$, $\sigma \times 5$

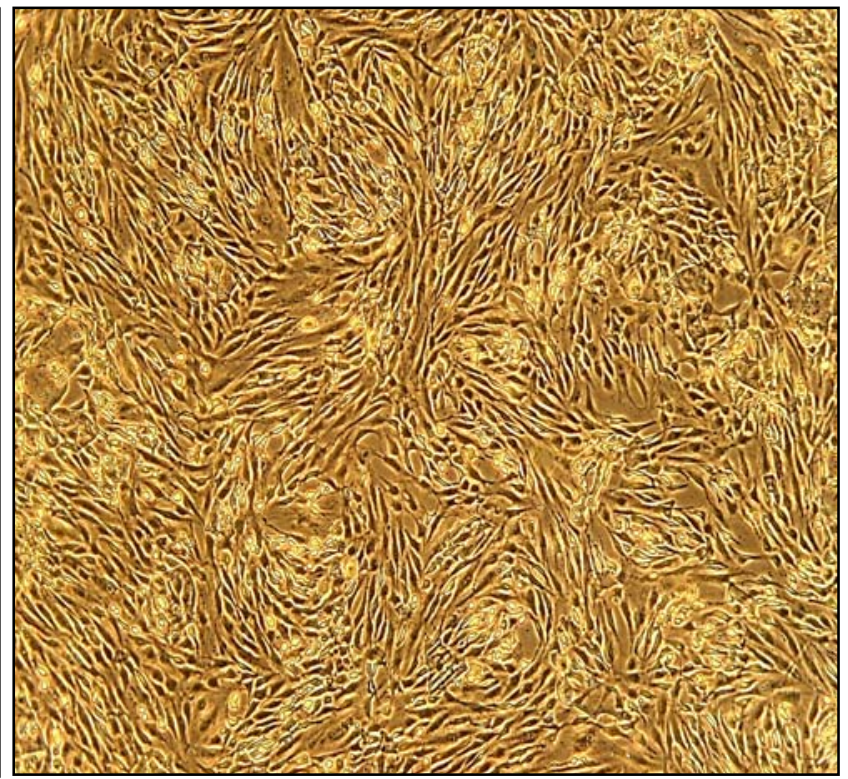

Рис. 4. Мікрофотографія моношару культури клітин жирової тканини in vitro, 1-й пасажс. Нативний препарат. ок. $\times 10$, об $\times 5$

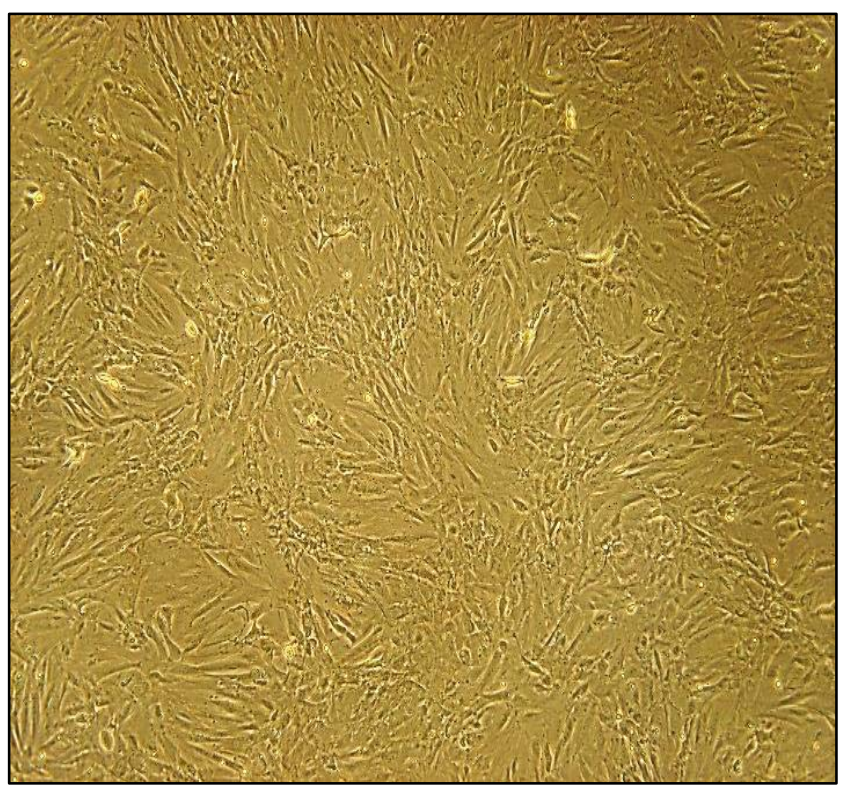

Рис. 6. Мікрофотографія моношару культури клітин жерової тканини in vitro, 4-й пасаж. Нативний препарат. ок. $\times 10, \sigma б \times 5$ 
ВЕТЕРИНАРНА МЕДИЦИНА

Порівняння зміни експресї̈ CD-маркерів у популяції клітин, виділених із жсирової тканини та кісткового мозку цура з периого по четвертий пасажс $(M \pm m, n=3)$

\begin{tabular}{|c|c|c|c|c|c|}
\hline \multirow{3}{*}{ CD-маркери } & \multirow{3}{*}{$\begin{array}{c}\text { Досліджувана } \\
\text { культура клітин }\end{array}$} & \multicolumn{4}{|c|}{ Пасаж } \\
\hline & & $\mathrm{I}$ & II & III & IV \\
\hline & & \multicolumn{4}{|c|}{ Оцінка в балах за методом H-Score (від 0 до 300 ) } \\
\hline \multirow{2}{*}{10} & KM & $0 \pm 0$ & $0 \pm 0$ & $0 \pm 0$ & $0 \pm 0$ \\
\hline & ЖТ & $0 \pm 0$ & $0 \pm 0$ & $11 \pm 5$ & $45 \pm 15^{*}$ \\
\hline \multirow{2}{*}{34} & KM & $108 \pm 8$ & $97 \pm 8$ & $92 \pm 2$ & $97 \pm 4$ \\
\hline & ЖТ & $93 \pm 5$ & $73 \pm 7$ & $41 \pm 11 *$ & $8 \pm 5 * * *$ \\
\hline \multirow{2}{*}{38} & KM & $116 \pm 9$ & $94 \pm 8$ & $57 \pm 7 * *$ & $38 \pm 11 * *$ \\
\hline & ЖT & $75 \pm 9$ & $55 \pm 3$ & $37 \pm 5^{*}$ & $14 \pm 5^{* *}$ \\
\hline \multirow{2}{*}{45} & KM & $95 \pm 12$ & $83 \pm 12$ & $76 \pm 13$ & $45 \pm 7 *$ \\
\hline & ЖТ & $74 \pm 6$ & $52 \pm 5^{*}$ & $23 \pm 7 * *$ & $5 \pm 3 * * *$ \\
\hline \multirow{2}{*}{48} & KM & $68 \pm 11$ & $75 \pm 15$ & $84 \pm 15$ & $115 \pm 13^{*}$ \\
\hline & ЖТ & $98 \pm 14$ & $76 \pm 15$ & $59 \pm 12$ & $26 \pm 3 * *$ \\
\hline \multirow{2}{*}{54} & KM & $0 \pm 0$ & $0 \pm 0$ & $0 \pm 0$ & $0 \pm 0$ \\
\hline & ЖT & $0 \pm 0$ & $0 \pm 0$ & $0 \pm 0$ & $0 \pm 0$ \\
\hline \multirow{2}{*}{56} & KM & $73 \pm 12$ & $85 \pm 8$ & $96 \pm 7$ & $84 \pm 7$ \\
\hline & ЖT & $0 \pm 0$ & $0 \pm 0$ & $0 \pm 0$ & $0 \pm 0$ \\
\hline \multirow{2}{*}{$66 \mathrm{e}$} & KM & $57 \pm 12$ & $78 \pm 11$ & $108 \pm 14^{*}$ & $115 \pm 15^{*}$ \\
\hline & ЖT & $248 \pm 10$ & $201 \pm 17$ & $103 \pm 16^{* *}$ & $66 \pm 7 * * *$ \\
\hline \multirow{2}{*}{95} & KM & $66 \pm 13$ & $79 \pm 15$ & $110 \pm 7 *$ & $119 \pm 9^{*}$ \\
\hline & ЖТ & $62 \pm 7$ & $91 \pm 22$ & $101 \pm 5^{*}$ & $126 \pm 13^{*}$ \\
\hline \multirow{2}{*}{227} & KM & $52 \pm 12$ & $68 \pm 13$ & $89 \pm 11$ & $83 \pm 9$ \\
\hline & ЖТ & $28 \pm 6,5$ & $46,3 \pm 15,3$ & $72,7 \pm 10,8^{*}$ & $49,7 \pm 9,0$ \\
\hline \multirow{2}{*}{326} & KM & $97 \pm 21$ & $87 \pm 19$ & $76 \pm 11$ & $37 \pm 6^{*}$ \\
\hline & ЖT & $0 \pm 0$ & $15 \pm 3^{* *}$ & $86 \pm 6^{* * *}$ & $87 \pm 7 * * *$ \\
\hline \multirow{2}{*}{ Кератин } & KM & $279 \pm 15$ & $259 \pm 20$ & $253 \pm 19$ & $193 \pm 16^{*}$ \\
\hline & ЖT & $82 \pm 7$ & $85 \pm 5$ & $71 \pm 4$ & $83 \pm 5$ \\
\hline
\end{tabular}

Примітка: $*-\mathrm{P}<0,05 ; * *-\mathrm{P}<0,01 ; * * *-\mathrm{P}<0,001$ порівняно 3 контролем (контролем для кожного CD-маркера виступав перший пасаж).

Характеристика культур клітин кісткового мозку та жирової тканини за поверхневими маркерами. Дослідження культур клітин кісткового мозку та жирової тканини показали відмінності у ïx імунофенотипі, які не зникали 3 пасажами. Більш докладно зміни експресії досліджуваних $\mathrm{CD}$-маркерів у зразках розглянемо нижче.

CD10 або ж нейтральна ендопептидаза відноситься до родини металопротеїназ [29], ступінь його експресії визначали як негативний упродовж усього періоду пасажування в обох досліджуваних культурах клітин.

CD34 - трансмембранний мономерний глікопротеїн I типу, що опосередковує процеси міжклітинної адгезії. Він є маркером гемопоетичних стовбурових клітин, ендотеліальних клітин судин, ембріональних фібробластів [20]. Під час дослідження у культурі клітин кісткового мозку відмічали підтримання рівня його експресії на одному рівні з незначними коливаннями, у той час як у ККЖТ відмічали різке зниження ступе- ню прояву CD34 аж до негативного на четвертому пасажі.

CD38 - одноланцюговий трансмембранний глюкопротеїд II типу [7], його молекула виявляється посередником кількох різних видів діяльності, включаючи передачу сигналу, клітинної адгезії і синтезу циклічної АДФ-рибози [21]. На першому пасажі відмічали низьку експресію $\mathrm{CD} 38$, що може свідчити про наявність у культуpi клітин-попередників. У подальшому рівень прояву даного маркера знижувався до негативного як у КККМ, так і в ККЖТ.

CD45 - трансмембранний глікопротеїн I типу, що належить до родини протеїн тирозин фосфатаз і експресується на всіх гемопоетичних клітинах, за винятком еритроцитів та тромбоцитів [30]. Даний факт може пояснювати достовірне зменшення експресії даного маркера в отриманій КККМ 395 (I пасаж) до 45 (IV пасаж) балів. Під час дослідження культури клітин жирової тканини на перших пасажах відмічали наявність 


\section{ВЕТЕРИНАРНА МЕДИЦИНА}

клітин, що експресують CD45, що відмічалося i в літературних даних [8], проте 3 пасажами його рівень знижувався до негативного.

CD48 - трансмембранний глікопротеїн I типу, зв'язаний 3 клітинною мембраною за допомогою глікозит фосфатидилінозита [28]. CD48 експресований на деяких гемопоетичних та ендотеліальних клітинах. Бере участь у активації і шляхах диференціації вказаних клітин. Під час дослідження відмічали достовірне зниження у ККЖТ експресії від низького до негативного ступеня, у той час як у КККМ ступінь прояву CD48 достовірно збільшувався від низького до помірного.

CD54 - одноланцюговий трансмембранний глікопротеїн I типу, який присутній на мембранах ендотеліальних клітин і має важливе значення для адгезії лейкоцитів [15]. Упродовж усього періоду культивування його експресії як у КККМ, так і в ККЖТ виявлено не було.

CD56 - трансмембранний глікопротеїн I типу, ізоформа молекули клітинної адгезії нейронів, що опосередковує розвиток нервової тканини, маркер NK-клітин, плазматичних клітин [13]. Упродовж усього періоду культивування його експресіі, яку в ККЖТ виявлено не було, у той час КККМ характеризувалася низьким рівнем експресії CD56 з першого до четвертого пасажу.

CD66e - глікозольований глюкопротеїд поверхневої мембрани епітеліальних клітин, чим пояснюється його виявлення у більшості органів [17]. У культурі клітин жирової тканини його експресія достовірно знижувалась 3 першого до четвертого пасажу, зворотню закономірність спостерігали у КККМ.

CD95 - трансмембранний глюкопротеїд I типу, опосередковує сигнал, що ініціює апоптоз [32]. Починаючи 3 першого пасажу інтенсивність експресії даного маркера достовірно збільшується у обох досліджуваних культурах. Дані росту експресії CD95 корелюють 3 рівнем апоптозу у культурі клітин кісткового мозку, що було досліджено нами раніше [2]. Отже 3 отриманих даних можна зробити висновок, що підвищення рівня CD95 пояснюється збільшенням клітин у стані апоптозу.

CD227 - трансмембранний глікопротеїн, що експресується епітеліальними та деякими гемопоетичними клітинами [19]. Гіперекспресія даного маркера призводить до трансформації клітин та нівелює стрес-індукований апоптоз через Akt або p53 каскади [26]. Під час дослідження нами відмічався низький ступінь експресії CD227 з незначними коливаннями, у той час як у культурі клітин жирової тканини ступінь прояву виходив за межі негативного лише на третьому пасажі і досягав своєї максимальної позначки 73 бали.

CD326 - трансмембранний глікопротеїн першого типу - маркер епітеліальних клітин. Клітини, що експресують даний маркер мають знижену потребу в факторах росту, спостерігають збільшення їх метаболічної активності і здатності до формування колоній [24]. У культурі клітин кісткового мозку відмічали зниження експресії CD326 від низького до негативного ступеня, водночас у культурі клітин жирової тканини відмічали зворотну закономірність.

Кератин - входить до складу проміжних філаментів цитоскелета епітеліальних клітин [12]. Наявність позитивної реакції з даними антитілами свідчить про епітеліальне походження клітин [23], цитокератин був виявлений у жировій тканині іншими науковцями $[1,31]$, за нашими ж результатами рівень експресії кератину у культурі клітин жирової тканини зберігався на одному рівні і характеризувався як низький. У культурі клітин кісткового мозку відмічали достовірне зменшення даного білка 3 високого до помірного ступеня.

Висновок. Результати наших досліджень показали, що первинна культура адгезивних клітин як жирової тканини, так і кісткового мозку складається 3 різних видів клітин, що пов'язано 3 різноманітністю вихідного пулу. Відмічали збільшення 3 пасажами у досліджуваних культурах клітин відсоткового вмісту фібробластоподібних клітин. Упродовж пасажування CD-профіль клітин у досліджуваних культурах змінювався 3 певними закономірностями. Виходячи зі спектру використаних CD-маркерів, характерних для неспеціалізованих (низькодиференційованих) клітин, активне зниження їх експресії з пасажами у ККЖТ (у порівнянні з КККМ) може свідчити про зниження універсальності даної культури та iii здатності до диференціації. Дана гіпотеза підтверджується достовірним зростанням CD95, що вказує на ініціацію апоптозу у культурі.

Різний фенотип культури клітин кісткового мозку та жирової тканини дасть змогу використовувати їх у подальшому у клітинній терапії та очікувати від них різного впливу за однакових умов. 


\section{БІБЛІОГРАФІЯ}

1. Кирик В. М. Стволовые клетки из жировой ткани: основные характеристики и перспективы клинического применения в регенеративной медицине (обзор литературы) / В. М. Кирик, Г. М. Бутенко // Журн. АМН України. - 2010. Том 16, №4. - С. 576-604.

2. Мазуркевич А. Й. Цитогенетичний аналіз мезенхімальних стовбурових клітин щурів на різних пасажах / А. Й. Мазуркевич, В. В. Ковпак, О. С. Ковпак та ін. // Ветеринарна біотехнологія. - 2016. - №28. - С. 165-172.

3. Мазуркевич А. Й. Клітинні технології у ветеринарній медицині : навчальний посібник / А. Й. Мазуркевич, В. В. Ковпак, В. Б. Данілов. К. : КОМПРИНТ, 2014. - 132 с.

4. Петренко А. Ю. Стволовые клетки из жировой ткани / А. Ю. Петренко, Э. Н. Иванов, Ю. А. Петренко // Біотехнологія. - 2008. - Том 1, №4. - C. 39-48.

5. Сухих Г. Т. Мезенхимальная стволовая клетка / Г. Т. Сухих, В. В. Малайцев, И. М. Богданова // Бюлл. эксперим. биол. и мед. $-2002 .-$ №2. - C. 124-131.

6. Упоров А. В. Иммуногистохимическое изучение клеток рака молочной железы с использованием разных маркеров пролиферации / А. В. Упоров, В. Ф. Семиглазов, К. М. Пожарисский // Арх. патологии. - 2000. - №2. - С. 26-30.

7. Alessio M. CD38 molecule: structural and biochemical analysis on human $\mathrm{T}$ lymphocytes, thymocytes, and plasma cells / M. Alessio, S. Roggero, A. Funaro et al // Immunol. - 1990. - Vol. 3 P. 878-884.

8. Astori G. «In vitro» and multicolor phenotypic characterization of cell subpopulations identified in fresh human adipose tissue stromal vascular fraction and in the derived mesenchymal stem cells / G. Astori, F. Vignati, S. Bardelli et al // J. Transl. Med. - 2007. - Vol.5, №1. - P. 55.

9. Aurich $H$. Hepatocyte differentiation of mesenchymal stem cells from human adipose tissue in vitro promotes hepatic integration in vivo / H. Aurich, M. Sgodda, P. Kaltwasser et al // Gut. 2009. - №58. - P. 570-581.

10. Bunnell B. A. Adipose-derived stem cells: isolation, expansion and differentiation / B. A. Bunnell, M. Flaat, Ch. Gagliardi et al // Methods. 2008. - №45 (2). - P. 115-120.

11. Carswell K. A. Culture of Isolated Human Adipocytes and Isolated Adipose Tissue / K. A. Carswell, Mi-Jeong Lee, S. K. Fried // Methods Mol Biol. - 2012. - №806. - P. 203-214.
12. Chang $L$. Intermediate filaments mediate cytoskeletal crosstalk / L. Chang, R. D. Goldman // Nat. Rev. Mol. Cell Biol. - 2004. - Vol.5, № 8 P. 601-613.

13. Cunningham B. A. Neural cell adhesion molecule: structure, immunoglobulin-like domains, cell surface modulation, and alternative RNA splicing / B. A. Cunningham, J. J. Hemperly, B. A. Murray // Science. - 1987. - №236 (4803). P. 799-806.

14. Dorshkind K. Stem cells and lineage plasticity: the challenge to existing paradigms / K. Dorshkind // Immunological Reviews. - 2002. Vol. 187. - P. 5-8.

15. Gay A. N. Wound healing characteristics of ICAM-1 Null mice devoid of all isoforms of ICAM$1 /$ A. N. Gay, O. P. Mushin, D. A. Lazar et al // J. Surg. Res. - 2011. - №171 (1) - e1-7.

16. Guilak $F$. Clonal analysis of the differentiation potential of human adipose-derived adult stem cells / F. Guilak, K. E. Lott, H. A. Awad et al// J. Cell Physiol. - 2006. - №206. - P. 229-237.

17. Hammarström $S$. The carcinoembryonic antigen (CEA) family: structures, suggested functions and expression in normal and malignant tissues / S. Hammarström // Semin. Cancer. Biol., 1999. - Vol. 9. - P. 67-81.

18. Freshney R. Ian. Culture of animal cells: a manual of basic technique / R. Ian Freshney. $-\left[5^{\text {th }}\right.$ ed.]. - USA : John Wiley \& Sons, 2005. - 642 p.

19. Inagaki Y. Clinicopathology of sialomucin: MUC1, particularly KL-6 mucin, in gastrointestinal, hepatic and pancreatic cancers / Y. Inagaki, H. Xu, M. Nakata et al // Biosci. Trends. - 2009. - №6. P. 220-232.

20. Krause D. S. CD34: structure, biology, and clinical utility / D. S. Krause, M. J. Fackler, C. I. Civin, W. S. May // Blood, 1996. - Vol. 87, №1. - P. 1-13.

21. Malavasi F. Human CD38: a glycoprotein in search of a function / F. Malavasi, A. Funaro, S. Roggero et al // Immunol. Today. - 1994. - №3. - P. 95-97.

22. Mitchell J. B. Immunophenotype of human adipose-derived cells: temporal changes in stromalassociated and stem cell-associated markers / J. B. Mitchell, K. McIntosh, S. Zvonic et al // Stem Cells. - 2006. - №24 (2). - P. 376-385.

23. Moll $R$. The catalog of human cytokeratins: patterns of expression in normal epithelia, tumors and cultured cells / R. Moll, W. W. Franke, D. L. Schiller, B. Geiger et al // Cell, 1982. Vol. 31, №1. - P. 11-24. 


\section{ВЕТЕРИНАРНА МЕДИЦИНА}

24. Münz $M$. The carcinoma-associated antigen EpCAM upregulates c-myc and induces cell proliferation / M. Münz, C. Kieu, B. Mack, B. Schmitt et al // Oncogene, 2004. - Vol. 23, №24. - P. 57485758.

25. Ningning He. Bone Marrow Vascular Niche: Home for Hematopoietic Stem Cells / He Ningning, Zhang Lu, Cui Jian et al // Hindawi Publishing Corporation: Bone Marrow Research, 2014. - Article ID 128436. - 8 pp.

26. Raina D. The MUC1 oncoprotein activates the anti-apoptotic phosphoinositide 3-kinase. Akt and Bcl-xL pathways in rat 3Y1 fibroblasts / D. Raina, S. Kharbanda, D. Kufe // Biol. Chem. 2004. - Vol. 279, №20. - P. 20607-20612.

27. Ruiz J. C. Differentiated human adiposederived stem cells exhibit hepatogenic capability in vitro and in vivo / J. C. Ruiz, J. W. Ludlow, S. Sherwood et al // J Cell Phys., 2010. - №225. P. 429-436.

28. Shin J. S. Glycosylphosphatidylinositolanchored receptor-mediated bacterial endocytosis / J. S. Shin, S. N. Abraham // FEMS Microbiol Lett. 2001. - Vol. 197, №2. - P. 131-138.
29. Shipp M. A. Common acute lymphoblastic leukemia antigen (CALLA) is active neutral endopeptidase 24.11 («enkephalinase»): direct evidence by cDNA transfection analysis / M. A. Shipp, J. Vijayaraghavan, E.V. Schmidt et al // Proc. Natl. Acad. Sci. USA, 1989. - №86 (1). - P. 297-301.

30. Trowbridge I. S. CD45: an emerging role as a protein tyrosine phosphatase required for lymphocyte activation and development / I. S. Trowbridge, M. L. Thomas // Annu. Rev. Immunol. - 1994. - №12. - P. 85-116.

31. Yang J. In vitro expression of cytokeratin 18, 19 and tube formation of adipose derived stem cells induced by the breast epithelial cell line HBL 100 / J. Yang, L. Xiong, R. Wang et al // J. Cell Mol. Med., 2015. - №19 (12). - P. 2827-2831.

32. Yonehara $S$. A cell-killing monoclonal antibody (anti-Fas) to a cell surface antigen codownregulated with the receptor of tumor necrosis factor / S. Yonehara, A. Ishii, M. Yonehara // Exp. Med., 1989. - Vol. 169, №5. - P. 1747-1756.

33. Zuk P. A. Multilineage cells from human adipose tissue: implications for cell-based therapies / P. A. Zuk, M. Zhu, H. Mizuno et al. // Tissue Eng., 2001. - №7. - P. 211-228. 